\title{
FAKTOR-FAKTOR YANG MEMPENGARUHI PERILAKU ETIS PROFESI AKUNTAN PENDIDIK (STUDI EMPIRIS PADA PERGURUAN TINGGI DI PROVINSI LAMPUNG)
}

\author{
Nedi Hendri dan Suyanto \\ nedi_hendri@yahoo.com dan yanto.metro@gmail.com \\ Universitas Muhammadiyah Metro \\ Jl. Ki Hajar Dewantara No.116 Kota Metro 34111
}

\begin{abstract}
ABSTRAK
The aim of this study was to determine the various factors that influence ethical behavior accounting profession educators in Lampung Province. Analysis of the data of this study are included in the quantitative research and aimed to test the hypothesis. Structural analysis of studies using Equetion Modeling (SEM) in order to obtain a comprehensive model of research results, both direct effect and indirect effect. The results showed that moral reasoning does not significantly affect the ethical behavior accountant educator. The findings of this study are not consistent with existing theory and do not support some of the results of previous studies which claim that moral reasoning would easily make a moral judgment and moral behavior. The influence of moral reasoning on the ethical behavior of the accounting profession educators tend to be straightforward. The findings of this study are consistent with existing theory and supports some of the results of previous studies which state that will facilitate one's professional experience make moral judgment and moral behavior. Ethical attitude will automatically bring ethical behavior as well. The influence of professional experience to the ethical behavior of the accounting profession educators tend to be direct or through locus of control.
\end{abstract}

\section{Keywords:}

Moral thinking, professional experience, locus of control and ethical behavior.

\section{PENDAHULUAN \\ Latar Belakang}

Etika merupakan suatu konsep fundamental bagi semua profesi, baik dibidang akuntansi, pemasaran, keuangan, pemerintahan dan lain-lain. Perilaku dan tindakan etis setiap orang akan memberikan dampak bagi orang lain dan bagi organisasi di mana ia menjadi bagiannya (Maryani dan Ludigdo, 2001). Perilaku dan tindakan etis menjadi bagian penting dari pelaksanaan Good Corporate Governance. Kesadaran akan pentingnya etika ini justru muncul ketika berbagai kasus yang terkait dengan pelanggaran etika terjadi, baik pada profesi akuntan maupun bisnis secara umum.

Krisis etika juga sedang terjadi pada profesi akuntansi dengan adanya temuan bahwa auitor ikut terlibat dalam menyetujui kecurangan pelaporan keuangan yang dilakukan oleh perusahaan-perusahaan besar seperti Enron, WorldCom, Tyco dan lain sebagainya. Perhatian yang ditujukan kepada profesi akuntansi ini disebabkan oleh beberapa faktor diantaranya adalah pelanggaran terhadap standar dan aturan yang berlaku terkait dengan kode etik profesi akuntansi. 
Pekerjaan seorang akuntan pendidik harus dikerjakan dengan sikap profesional dengan sepenuhnya berlandaskan pada standar moral dan etika yang telah ditetapkan dalam Perguruan Tinggi. Dengan sikap profesionalnya seorang akuntan pendidik akan mampu menghadapi berbagai tekanan yang dapat muncul dari dirinya sendiri ataupun pihak eksternal. Profesi akuntan pendidik juga harus mengakui pentingnya nilai-nilai etika karena nilai-nilai etika personal tersebut mempunyai pengaruh terhadap prilaku etis tidaknya keputusan yang diambil oleh seorang akademisi.

Etika menurut Arens dan Loebbecke (1997) didefinisikan sebagai perangkat prinsip moral atau nilai. Pelanggaran etika yang terjadi dalam Perguruan Tinggi dapat berupa plagiat karya ilmiah, kekerasan terhadap mahasiswa, pemberian nilai akademik yang tidak adil, pelecehan seksual, dan sebagainya. Jika prilaku etis tidak dijalankan dengan benar maka kasus-kasus penyimpangan tersebut akan banyak terjadi.

Penyimpangan-penyimpangan dalam akademik tidak akan terjadi apabila setiap profesional pendidik ini mempunyai pengetahuan, pemahaman, kemauan untuk menerapkan nilai-nilai moral dan etika secara memadai dalam pelaksanaan pekerjaan profesionalnya (Ludigdo dan Machfoedz, 1999). Oleh karena itu, terjadinya berbagai kasus sebagaimana disebutkan di atas, seharusnya memberikan kesadaran untuk lebih memperhatikan etika dalam melaksanakan pekerjaan profesi khususnya sebagai akuntan pendidik.

Penelitian atas persoalan moral sebagian besar berfokus profesi akuntan publik, dengan tiga kelompok kajian utama, yaitu:

1. Pengembangan Moral (Ethical developement)

2. Pertimbangan Moral (Ethical Judgment), dan

3. Pendidikan Etika (Ethics Education)

Penelitian pengembangan moral berusaha mencari pokok-pokok yang mendasari proses pemikiran moral dalam praktik. Penelitian pertimbangan moral, menguji hubungan antara pemikiran moral dan perilaku moral, sedangkan Penelitian dalam pendidikan etika menginvestigasi tentang keefektifan campur tangan pendidikan dalam memecahkan atau memperbaiki sikap moral dan keahlian atau pengetahuan tentang pemikiran moral mahasiswa maupun praktisi.

Menurut Arens dan Loebbecke (1997) banyak penjelasan tentang mengapa ada orang yang fokus pada nilai moral dalam membuat pemikiran moral secara serius seperti sebuah catatan dalam perjanjian dari motivasi moral yang memberikan ide dari justifikasi yang lama terhadap penekanan motivasi moral kedalam bidang moral.

Disisi lain, karakter moral berkenaan dengan personaliti, seperti kekuatan ego, keteguhan ego, kegigihan, kekerasan hati, pemikiran dan kekuatan akan pendirian serta keberanian yang berguna untuk melakukan tindakan yang benar (Rest, 1986). Seorang individu yang memiliki kemampuan dalam menentukan apa yang secara moral baik atau buruk dan benar atau salah, mungkin bisa gagal atau salah dalam berkelakuan secara moral sebagai hasil dari kegagalan dalam mengidentifikasi persoalan-persoalan moral (Kohlberg, 1983). Dalam berkelakuan secara moral seorang individu dipengaruhi oleh faktor-faktor individu yang dimilikinya.

Penelitian mengenai faktor-faktor yang berpengaruh terhadap perilaku etis individu dalam pengambilan keputusan telah dilakukan oleh peneliti-peneliti terdahulu. Banyak penelitian sebelumnya di Indonesia membahas mengenai pembuatan keputusan etis, akan tetapi lebih difokuskan pada karakteristik personal yang dimiliki individu seperti gender, usia, pendidikan, tingkat moralitas, maupun faktor-faktor organisasional seperti iklim etis 
organisasi, pengaruh kelompok sejawat, dan kode etik seperti yang dilakukan oleh Nugrahaningsih (2005) yang menguji perbedaan evaluasi etis, intensi etis dan orientasi etis dilihat dari gender dan latar belakang disiplin ilmu mahasiswa, Maryani dan Ludigdo (2001) dengan hasil surveinya yang mendeskripsikan secara parsial faktor-faktor yang mempengaruhi sikap dan perilaku etis profesi, dan lain-lain. Namun demikian, penelitian mengenai nilai-nilai personal seperti pemahaman moral, pengalaman profesi dan locus of control yang mempengaruhi perilaku etis bagi akuntan pendidik belum banyak dilakukan.

\section{Rumusan Masalah}

Berbagai kasus pelanggaran etika seharusnya tidak terjadi apabila setiap akuntan mempunyai pengetahuan, pemahaman, dan kemauan untuk menerapkan nilai-nilai moral dan etika secara memadai dalam pelaksanaan pekerjaannya sebagai pendidik. Oleh karena itu, terjadinya kasus sebagaimana disebutkan di atas, seharusnya memberi kesadaran untuk lebih memperhatikan etika dalam melaksanakan pekerjaan profesi termasuk akuntan pendidik. Sudibyo (1995) dalam Khomsiyah \& Indriantoro (1998) mengemukakan bahwa dunia pendidikan mempunyai pengaruh yang besar terhadap perilaku etika. Ungkapan tersebut mengisyaratkan bahwa sikap dan perilaku moral dapat terbentuk melalui proses pendidikan. Lebih dari itu, akuntan pendidik merupakan pelaksana utama dalam aktivitas belajar mengajar jurusan akuntansi sehingga sedikit banyaknya akan berpengaruh terhadap proses pendidikan yang pada akhirnya pada profesi akuntansi secara keseluruhan.

Berdasarkan latar belakang yang telah diuraikan sebelumnya, maka masalah penelitian dapat dirumuskan sebagai berikut:

1. Apakah pemikiran moral berpengaruh secara langsung terhadap perilaku etis akuntan pendidik?

2. Apakah pengalaman profesi berpengaruh secara langsung terhadap perilaku etis akuntan pendidik?

3. Apakah pemikiran moral berpengaruh tidak langsung terhadap perilaku etis akuntan pendidik melalui locus of control?

4. Apakah pengalaman profesi berpengaruh tidak langsung terhadap perilaku etis akuntan pendidik melalui locus of control?

\section{PENGEMBANGAN HIPOTESIS \\ Teori Etika}

Prinsip-prinsip etika tidak berdiri sendiri, tetapi tercantum dalam suatu kerangka pemikiran sistematis yang disebut "teori". Teori etika menyediakan kerangka yang memungkinkan seseorang memastikan benar tidaknya keputusan moral. Berdasarkan suatu teori etika, keputusan moral yang diambil seseorang dapat menjadi beralasan dan secara logis dapat diterima keberadaannya. Suatu teori etika membantu manusia untuk mengambil keputusan moral dan menyediakan justifikasi untuk keputusan tersebut (Kohlberg, 1983).

Etika, dalam bahasa latin "ethica", berarti falsafah moral. Etika merupakan pedoman cara bertingkah laku yang baik dari sudut pandang budaya, susila serta agama. Istilah etika jika dilihat dalam Kamus Besar Bahasa Indonesia (1998), memiliki tiga arti, 
yang salah satunya adalah nilai mengenai benar dan salah yang dianut suatu golongan atau masyarakat. Sedangkan menurut Keraf (1998), etika secara harfiah berasal dari kata Yunani ethos (jamaknya: ta etha), yang artinya sama persis dengan moralitas, yaitu adat kebiasaan yang baik. Adat kebiasaan yang baik ini lalu menjadi sistem nilai yang berfungsi sebagai pedoman dan tolak-ukur tingkah laku yang baik dan buruk.

Etika merupakan suatu prinsip moral dan perbuatan yang menjadi landasan bertindak seseorang sehingga apa yang dilakukannya dipandang oleh masyarakat sebagai perbuatan terpuji dan meningkatkan martabat dan kehormatan seseorang (Munawir, 1997). Etika sangat erat kaitannya dengan hubungan yang mendasar antar manusia dan berfungsi untuk mengarahkan perilaku bermoral. Moral adalah sikap mental dan emosional yang dimiliki individu sebagai anggota kelompok sosial dalam melakukan tugas-tugas atau fungsi yang diharuskan kelompoknya serta loyalitas pada kelompoknya.

Dari beberapa definisi di atas dapat disimpulkan bahwa etika merupakan seperangkat aturan/norma atau pedoman yang mengatur perilaku manusia, baik yang harus dilakukan maupun yang harus ditinggalkan yang dianut oleh sekelompok/segolongan manusia/masyarakat atau profesi. Etika merupakan refleksi kritis dan rasional mengenai (a) nilai dan norma yang menyangkut bagaimana manusia harus hidup baik sebagai manusia; dan mengenai (b) masalah-masalah kehidupan manusia dengan mendasarkan diri pada nilai dan norma-norma moral yang umum diterima. Secara umum ada beberapa teori yang penting dalam pemikiran moral, khususnya dalam etika bisnis yaitu teleologis/utilitarianisme, egoisme, deontologi, teori hak dan teori keutamaan (Keraf, 1998).

Teori teleologis menyatakan bahwa kualitas etis suatu perbuatan diperoleh dengan dicapainya tujuan perbuatan. Teori ini terpecah menjadi utilitarianisme dan egoisme. Utilitarianisme menyatakan bahwa perbuatan disebut etis jika membawa manfaat bagi masyarakat secara keseluruhan. Sedangkan egoisme berarti bahwa satu-satunya tujuan tindakan moral setiap orang adalah mengejar kepentingan pribadi dan memajukan dirinya.

Deontologi menyatakan bahwa supaya suatu tindakan punya nilai moral, tindakan itu harus dijalankan berdasarkan kewajiban. Nilai moral dari tindakan itu tidak tergantung pada tercapainya tujuan dari tindakan itu melainkan tergantung pada kemauan baik yang mendorong seseorang untuk melakukan tindakan itu-berarti kalaupun tujuannya tidak tercapai, tindakan itu sudah dinilai baik.

Teori hak berakar dari teori dentologi, karena hak berkaitan dengan kewajiban. Hak didasarkan atas martabat manusia dan martabat semua manusia itu sama, sehingga manusia individual siapapun tidak pernah boleh dikorbankan demi tercapainya suatu tujuan yang lain.

Teori keutamaan (virtue theory) merupakan pendekatan yang tidak menyoroti perbuatan, tetapi memfokuskan pada seluruh manusia sebagai pelaku moral. Di dalam teori ini tidak ditanyakan: "what should he/she do?" melainkan: "what kind of person should he/she be?". Tidak ditanyakan apakah suatu perbuatan tertentu adil atau jujur, melainkan apakah orang itu bersikap adil, jujur dan sebagainya.

\subsection{Pemikiran Moral}

Pemikiran moral mengacu pada penggunaan beberapa alasan untuk menilai sesuatu kegiatan bisnis sebagai etika atau bukan. Ada empat gaya pemikiran yang mencerminkan hirarki dari pengembangan moral, yang mengingatkan apa tujuan 
pengembangan moral (Kohlberg et al., 1983). Empat gaya pemikiran tersebut adalah deontological, teleological, egois atau conventional (Fraedrich dan Ferrell, 1992a, 1992b; Harris dan Sutton, 1995; Reindenbach dan Robin, 1990).

Pemikiran deontological berfokus pada maksud untuk merealisasikan tujuan-tujuan yang penting, ideal, dan nilai-nilai yang diinginkan secara umum, yaitu meliputi kesetiaan (Barnett et al., 1994; Ellenwood \& Ryan, 1991). Pada pendekatan deontological, perhatian tidak hanya pada perilaku dan tindakan, namun lebih pada bagaimana orang melakukan usaha dengan sebaik-baiknya dan mendasarkan pada nilainilai kebenaran untuk mencapai tujuannya. Pemikiran teleological menekankan dalam maksimalisasi yang bermanfaat untuk masyarakat atau sebanyak-banyaknya orang. Pada pendekatan teleological, perhatian tidak hanya pada perilaku dan tindakan, namun lebih pada bagaimana mencapai tujuan dengan sebaik-baiknya. Pemikiran conventional mengacu pada penyesuaian hukum, norma, dan kode etik professional. Pemikiran egois memperoleh kebaikan dari kepentingan untuk dirinya sendiri. Oleh karena itu, hirarki akan memberikan tingkatan dari pengembangan etika dari egois ke conventional lalu ke teleological dan akhirnya ke deontological.

Teori pengembangan moral mengenai pemikiran moral sangat penting sebagai konsep dari etika. Pemikiran moral akan mudah membuat pertimbangan moral dan perilaku moral.

Kemudahan ini akan mencerminkan hak yang lebih tinggi dari pengembangan kognitif dalam pertimbangan dan perilaku. Oleh karena itu, seseorang cenderung untuk mempunyai pertimbangan moral menurut tingkat dari pengembangan dalam pemikiran moral seseorang.

\subsection{Pengalaman Profesi}

Beberapa pengalaman profesi yang relevan dapat mempengaruhi sikap etis apabila pengalaman profesi tersebut meninggalkan kesan yang kuat. Kesan positif yang kuat dapat terbentuk apabila pengalaman profesi tersebut terjadi dalam situasi yang melibatkan faktor emosional. Sikap etis secara otomatis akan memunculkan perilaku etis juga. Barney (1992 dalam Beekun 1997: 7), berpendapat bahwa pengalaman profesi seseorang baik yang positif maupun negatif merupakan kunci yang menjadi dasar munculnya sikap dan perilaku selanjutnya. Apabila seseorang dapat mengambil pelajaran dari pengalaman profesinya masa lalu maka akan menumbuhkan sikap dan perilaku yang semakin etis.

\subsection{Locus of Control}

Menurut Falah (2007) Locus of control merupakan salah satu faktor individual yang mempengaruhi cara pandang seseorang terhadap suatu peristiwa, bisa tidaknya ia mengendalikan peristiwa tersebut, serta dorongan untuk menjadi seseorang/sesuatu sesuai dengan ambisinya (Robbins, 2006). Locus of control mengenai kekuatankekuatan dari gaya yang dipercaya oleh seorang individu sebagai bentuk tanggung jawab terhadap ganjaran dan hukuman yang terjadi padanya (Rotter, 1966). Seseorang yang dicirikan atau diwatakkan sebagai "eksternal" percaya bahwa dia adalah seorang korban dari nasib, kesempatan, kekuasaan yang lain dan bahwa dia sedikit memiliki control mengenai nasib baik atau keuntungan yang akan menimpanya. 
Sebaliknya, seseorang yang "internal" percaya bahwa tingkah laku seseorang menentukan apa yang akan terjadi pada seseroang adalah pemilik nasib baik seseorang. Locus of control telah dianggap suatu dari ciri watak kepribadian yang lebih teguh atau stabil yang ada pada diri seorang individu (Koford dan Pennu, 1992). Dalam literatur moral menyatakan bahwa locus of control sebagai suatu ciri watak kepribadian memberikan pengaruh pada pembuatan keputusan dan tingkah laku (Chiu, 2003 dalam Chan dan Leung, 2006).

\subsection{Perilaku Etis Profesi}

Definisi sikap menurut Krech dan Crutcfield (1983) yang dikutip Maryani dan Ludigdo (2001) adalah keadaan dalam diri manusia yang menggerakkan untuk bertindak, menyertai manusia dengan perasaan perasaan tertentu dalam menanggapi obyek dan terbentuk atas dasar pengalaman-pengalaman. Sikap merupakan tenaga pendorong (motif) dari seseorang untuk timbulnya sesuatu perbuatan atau tingkah laku. Sikap yang ada pada seseorang akan menentukan warna atau corak pada tingkah laku orang tersebut. Dengan mengetahui sikap seseorang maka akan dapat diduga respons atau perilaku yang akan diambil oleh seseorang terhadap masalah atau keadaan yang dihadapkan padanya.

Pembentukan atau perubahan sikap ditentukan oleh dua faktor pokok, yaitu faktor individu dan faktor luar. Faktor individu atau faktor internal adalah bagaimana individu menanggapi dunia luarnya secara selektif. Sedangkan faktor luar atau ekstern adalah halhal atau keadaan dari luar yang merupakan rangsangan atau stimulus untuk membentuk atau mengubah sikap. Mc.Conell (dalam Maryani dan Ludigdo, 2001) menyatakan bahwa perilaku kepribadian merupakan karakteristik individu dalam menyesuaikan diri dengan lingkungannya. Karakteristik yang dimaksud meliputi: sifat, kemampuan, nilai, ketrampilan, sikap serta intelegensi yang muncul dalam pola perilaku seseorang. Jadi perilaku merupakan perwujudan atau manifestasi karakteristik seseorang dalam menyesuaikan diri dengan lingkungannya.

Griffin dan Ebert (1998) mendefinisikan perilaku etis sebagai perilaku yang sesuai dengan norma-norma sosial yang diterima secara umum sehubungan dengan tindakan-tindakan yang bermanfaat dan yang membahayakan. Sementara Socrates menyatakan bahwa yang dimaksud dengan tindakan etis atau perilaku etis adalah tindakan yang didasarkan pada nilai-nilai kebenaran, benar dari sisi cara, teknik, prosedur maupun dari sisi tujuan yang dicapai (Syafruddin, 2005 dalam Falah, 2005). Menurut Morgan. 1993 yang dikutip Nugrahaningsih, 2005 perilaku etis juga sering disebut sebagai komponen dari kepemimpinan yang mana pengembangan etika adalah hal penting bagi kesuksesan individu sebagai pemimpin suatu organisasi.

Perilaku yang beretika dalam organisasi adalah melaksanakan tindakan secara fair sesuai hukum konstitusional dan peraturan pemerintah yang dapat diaplikasikan (Steiner dalam Reiss dan Mitra, 1998). Apabila seorang auditor melakukan tindakan-tindakan yang tidak etis maka tindakan tersebut akan merusak kepercayaan masyarakat terhadap profesi auditor itu (Khomsiyah \& Indriantoro, 1998). Larkin (2000) menyatakan bahwa kemampuan untuk dapat mengidentifikasi perilaku etis dan tidak etis sangat berguna dalam semua profesi termasuk akuntan.

Berdasarkan kajian teoritis menunjukkan adanya pola hubungan antar variabel yang meliputi pemahaman moral, pengalaman profesi, locus of control dan prilaku etis dosen. 
Atas dasar tersebut, maka kerangka pemikiran penelitian ini dapat gambarkan sebagai berikut :

Dengan demikian, hipotesisi yang diajukan adalah sebagai berikut:

H1 = Pemikiran moral berpengaruh secara langsung terhadap prilaku etis profesi akuntan pendidik.

$\mathrm{H} 2$ = Pengalaman profesi berpengaruh secara langsung terhadap prilaku etis profesi akuntan pendidik.

H3 = Pemikiran moral berpengaruh tidak langsung terhadap prilaku etis profesi akuntan pendidik melalui locus of control.

H4 = Pengalaman profesi berpengaruh tidak langsung terhadap prilaku etis profesi akuntan pendidik melalui locus of control.

Gambar 1: Model Kerangka Pikir Teoritis

Faktor-faktor yang Mempengaruhi Perilaku Etis Profesi Akuntan Pendidik

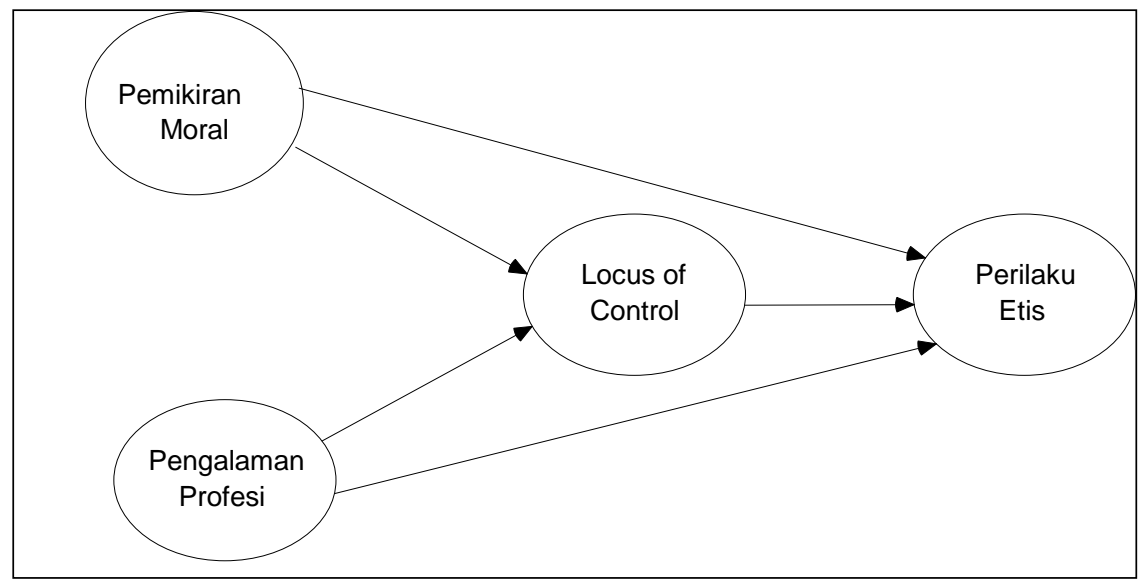

\section{METODE PENELITIAN}

\section{Rancangan Penelitian}

Penelitian tentang model pengaruh pengembangan perilaku etis profesi akuntan pendidik di propinsi Lampung ini merupakan salah satu penelitian yang dilakukan secara Cross Section. Penelitian difokuskan melalui studi atas pemahaman moral, pengalaman profesi, locus of control terhadap perilaku etis dosen. Penelitian ini ditujukan untuk menguji hipotesis, sehingga dapat dikategorikan sebagai metode penelitian kuantitatif (quantitative research).

\section{Variabel Penelitian}

Variabel penelitian ini terdiri dari: Pertama, Variabel eksogen yaitu terdiri dari pemahaman moral dan pengalaman profesi yang mempengaruhi nilai variabel lain dalam model. Pemikiran moral adalah mengarah pada pembuatan sebuah pertimbangan mengenai apakah kebenaran pasti dari tindakan secara moral seperti yang seharusnya dilakukan. Proses dari tahapan ini meliputi pemikiran perspektif dari pertimbangan profesionalnya dalam sebuah pemecahan yang ideal untuk sebuah dilema moral (Thorne, 
2000). Sedangkan pengalaman profesi merupakan pengalaman yang relevan dengan profesi seseorang baik yang positif maupun negatif dan menjadi faktor kunci sebagai dasar munculnya sikap dan perilaku( Barney, 1992 dalam Beekun 1997).

Kedua, Variabel endogen yaitu locus of control dan perilaku etis dosen yang dipengaruhi oleh variabel eksogen dalam model, baik pengaruh secara langsung maupun tidak langsung. Locus of control merupakan suatu dari ciri watak kepribadian yang lebih teguh atau stabil yang ada pada diri seorang individu (Robbins, 2006). Perilaku etis merupakan tindakan yang didasarkan pada nilai-nilai kebenaran, benar dari sisi cara, teknik, prosedur maupun dari sisi tujuan yang dicapai (Syafruddin, 2005 dalam Falah, 2005).

\section{Metode Pengumpulan data}

Pengumpulan data dilakukan dengan menggunakan kuesioner yang dikirimkan kepada responden. Kuesioner yaitu pengumpulan data melalui daftar pertanyaan/pernyataan tertulis yang disusun untuk mendapatkan informasi atau keterangan dari beberapa orang. Pendistribusian kuesioner penelitian ini dilakukan dengan cara mail survey, dimana kuesioner disampaikan secara langsung maupun tidak langsung (melalui jasa PT. Pos Indonesia) kepada akuntan pendidik yang terdapat di perguruan tinggi se-propinsi Lampung.

\section{Analisis Data}

\section{Statistik Deskriptif}

Analisis deskriptif dilakukan dalam penelitian ini untuk mengetahui gambaran secara umum mengenai data responden penelitian. Menurut Ghozali (2008), statistik deskriptif memberikan gambaran atau deskripsi suatu data yang dilihat dari nilai rata-rata (mean), standar deviasi, varian, maksimum dan minimum data yang menggambarkan profil responden.

\section{Analisis Structural Equation Modeling (SEM)}

Semua hipotesis penelitian ini akan dianalisis menggunakan Structural Equation Modeling (SEM) dengan software AMOS versi 16.0. Berdasarkan kajian teoritis yang ada dapat dibuat gambar diagram jalur hubungan kausalitas antar konstruk beserta indikatornya sebagai berikut:

Penelitian ini akan menguji hubungan kausalitas sehingga menggunakan matriks varian dan kovarian (Hair et al. 1998). Teknik estimasi yang dipergunakan adalah Maximum Likelihood Estimation. Estimasi structural equation model dilakukan dengan analisis full model untuk melihat kesesuaian model dan hubungan kausalitas yang dibangun dalam model uji.

\section{Pengujian Hipotesis}

Untuk menguji hipotesis mengenai kausalitas yang dikembangkan dalam model ini, perlu diuji hipotesis nol yang menyatakan bahwa koefisien regresi antara hubungan adalah sama dengan nol melalui pengamatan terhadap nilai regression weight pada kolom critical ratio (CR) yang dihasilkan oleh program AMOS. Nilai CR dibandingkan dengan nilai kritisnya yaitu $\pm 1,96$ dengan tingkat signifikansi 0,05 . Apabila nilai CR $> \pm$ 1,96 dengan tingkat signifikansi $<0,05$ maka varibel eksogen berpengaruh terhadap 
variabel endogen. Dan apabila nilai $\mathrm{CR}< \pm 1,96$ dengan tingkat signifikansi $>0,05$ maka varibel eksogen tidak berpengaruh terhadap variabel endogen.

Sedangkan Pengaruh langsung dan pengaruh tidak langsung model yang dianalisis dapat diidentifikasi melalui path coefficients yang dihasilkan oleh program Amos. Dari path coefficients tersebut perlu dipisahkan antara pengaruh total standar dari pengaruh langsung standar. Apabila pengaruh total standar sama dengan pengaruh langsung standar menunjukkan tidak terdapat pengaruh lain yang dapat mempengaruhi perilaku etis akuntan pendidik di Propinsi Lampung. Sebaliknya, jika pengaruh total standar tidak sama dengan pengaruh langsung standar maka dapat diketahui besarnya pengaruh masing-masing dari coefficient tersebut.

\section{HASIL PENELITIAN}

\section{Responden Penelitian}

Adapun profil 91 responden yang berpartisipasi dan digunakan dalam penelitian ini ditunjukkan pada tabel sebagai berikut:

Tabel 1

Profil Responden

\begin{tabular}{lrc}
\hline \hline & Jumlah & Persentase \\
Lama menjadi tenaga pendidik & & \\
- $>5$ tahun & 46 & $50,55 \%$ \\
- $2-5$ tahun & 34 & $37,36 \%$ \\
- 2 tahun & 11 & $12,09 \%$ \\
Jenis Kelamin & & \\
- Pria & 59 & $64,83 \%$ \\
- Wanita & 32 & $35,17 \%$ \\
Pendidikan terakhir: & & \\
- S1 & 7 & $7,69 \%$ \\
- S2 & 71 & $78,02 \%$ \\
- S3 & 13 & $14,29 \%$ \\
\hline
\end{tabular}

Sumber: data primer diolah 2010

Tabel 1 diatas menginformasikan bahwa responden yang berpengalaman sebagai akuntan pendidik lebih dari 5 tahun berjumlah 46 orang $(50,55 \%)$, berpengalaman antara 2 sampai 5 tahun berjumlah 34 orang $(37,36 \%)$, dan berpengalaman kurang dari 2 tahun berjumlah 11 orang (12,09\%). Sedangkan berdasarkan gendernya, responden pria berjumlah 59 orang $(64,83 \%)$ dan wanita berjumlah 32 orang $(35,17 \%)$. Responden mayoritas memiliki latar belakang pendidikan S2 sebanyak 71 orang $(78,02 \%)$ dan sisanya berpendidikan S1 sebanyak 7 orang $(7,69 \%)$ dan S3 sebanyak 13 orang $(14,29 \%)$.

\section{Full Structural Equation Model Analysis}

Langkah selanjutnya setelah melakukan analisis faktor konfirmatori masing-masing konstruk adalah melakukan analisis full structural equation model. Analisis ini dilakukan 
dengan tetap memperhatikan proses analisis faktor konfirmatori per konstruk, dengan demikian proses tersebut menguji model secara keseluruhan dengan menggunakan model per konstruk sehingga terbentuk model yang baik. Analisis model persamaan struktural secara penuh (full structural equation model analysis) dapat dilihat pada gambar sebagai berikut.

Gambar 2. Full Structural Equation Model

Faktor-faktor yang Mempengaruhi Perilaku Etis Akuntan Pendidik

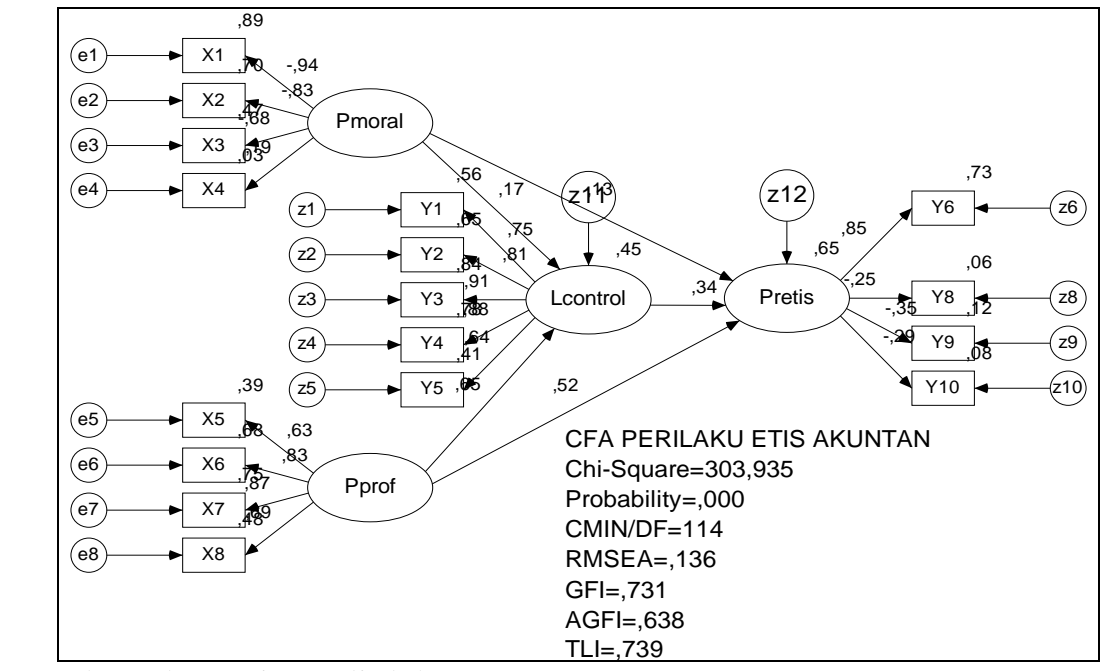

Sumber: data primer diolah (Output AMOS), 2014

\section{Pengujian Hipotesis}

Output table pengujian hipotesis penelitian dengan menggunakan program AMOS versi 16.0 dalam bentuk output Regression Weights nampak pada tabel 2. Kriteria pengujian hipotesis (Ghozali, 2007) adalah sebagai berikut:

a. Nilai CR (critical ratio) $>1,96$ dengan tingkat signifikansi $<0,05$ maka berarti varibel eksogen berpengaruh terhadap variabel endogen.

b. Nilai CR (critical ratio) < 1,96 dengan tingkat signifikansi $>0,05$ maka berarti varibel eksogen tidak berpengaruh terhadap variabel endogen.

Sedangkan uji tanda hubungan variabel eksogen terhadap variabel endogen dengan melihat nilai estimate standardized regression weights yang ditunjukkan tabel 3 berikut ini.

Tabel 2

Output Regression Weights

\begin{tabular}{|c|c|c|c|c|c|c|}
\hline \multicolumn{3}{|c|}{ Variabel } & Estimate & S.E. & C.R. & $\mathrm{P}$ \\
\hline Lcontrol & $<--$ & Pprof & 0,652 & 0,111 & 4,377 & $* *$ \\
\hline Lcontro & $<---$ & Pmoral & 0,167 & 0,380 & 1,230 & 0,219 \\
\hline Pretis & $<---$ & Pmor & 0,130 & 0,592 & 1,022 & 0,307 \\
\hline Pretis & $<---$ & Pprof & 0,525 & 0,194 & 3,342 & $* * *$ \\
\hline Pretis & $<---$ & Lcontrol & 0,335 & 0,244 & 2,284 & 0,022 \\
\hline
\end{tabular}

Sumber: data primer diolah 2014 
Tabel 3

Standardized Regression Weights

\begin{tabular}{|c|c|c|}
\hline & Variabel & Estimate \\
\hline Lcontrol & <--- $\quad$ Pprof & 0,652 \\
\hline Lcontrol & $<---\quad$ Pmoral & 0,167 \\
\hline Pretis & $<---\quad$ Pmoral & 0,130 \\
\hline Pretis & $<---$ Pprof & 0,525 \\
\hline Pretis & <--- Lcontrol & 0,335 \\
\hline
\end{tabular}

Sumber: data primer diolah 2014

Keterangan:
Pmoral = Pemikiran Moral
Lcontrol $=$ Locus of Control
Pprof = Pengalaman Profesi
Preti $=$ Prilaku Etis Akuntan Pendidik

\section{Pengujian Hipotesis $\left(\mathrm{H}_{1}\right.$ dan $\left.\mathrm{H}_{2}\right)$}

Hipotesis 1 menyatakan bahwa pemikiran moral berpengaruh secara langsung terhadap prilaku etis profesi akuntan pendidik. Hasil uji terhadap parameter estimasi (standardized regression weight) antara pemikiran moral (Pmoral) terhadap prilaku etis profesi akuntan pendidik (Pretis) menunjukkan adanya pengaruh sebesar 0,130 . Nilai critical ratio $(\mathrm{CR})$ sebesar 1,022 dengan nilai p-value pada tingkat signifikansi 0,307. Karena nilai $C R<1,96$ dan signifikansi $>0,05$ maka menunjukkan bahwa pemikiran moral (Pmoral) tidak berpengaruh langsung secara signifikan terhadap prilaku etis profesi akuntan pendidik (Pretis). Dengan demikian hipotesis 1 ditolak.

Hipotesis 2 menyatakan bahwa pengalaman profesi berpengaruh secara langsung terhadap prilaku etis profesi akuntan pendidik. Hasil uji terhadap parameter estimasi (standardized regression weight) antara pengalaman profesi (Pprof) terhadap prilaku etis profesi akuntan pendidik (Pretis) menunjukkan adanya pengaruh sebesar 0,525. Nilai critical ratio (CR) sebesar 3,342 dengan nilai p-value pada tingkat signifikansi 0,000 . Karena nilai $\mathrm{CR}>1,96$ dan signifikansi $<0,05$ maka menunjukkan bahwa pengalaman profesi (Pprof) berpengaruh langsung secara langsung terhadap prilaku etis profesi akuntan pendidik (Pretis). Dengan demikian hipotesis 2 diterima.

\section{Pengujian Hipotesis $\left(\mathrm{H}_{3}\right.$ dan $\left.\mathrm{H}_{4}\right)$}

Untuk menguji hipotesis yang berkaitan dengan pengaruh tidak langsung antar pemikiran moral (Pmoral) dan pengalaman profesi (Pprof) terhadap prilaku etis profesi akuntan pendidik (Pretis) melalui locus of control (Lcontrol), didasarkan pada tabel sebagai berikut:

Tabel 4 Standardized Direct Effects, Indirect Effects dan Total Effects

\begin{tabular}{|c|c|ccc|}
\hline $\begin{array}{c}\text { Independent } \\
\text { variable }\end{array}$ & $\begin{array}{c}\text { Dependent } \\
\text { variable }\end{array}$ & $\begin{array}{c}\text { Direct } \\
\text { effects }\end{array}$ & $\begin{array}{c}\text { Indirect } \\
\text { effects }\end{array}$ & $\begin{array}{c}\text { Total } \\
\text { effects }\end{array}$ \\
\hline Pmoral & Lcontrol & 0,167 & - & 0,652 \\
Pprof & Lcontrol & 0,652 & - & 0,167 \\
Pmoral & Pretis & 0,130 & 0,056 & 0,186 \\
Pprof & Pretis & 0,525 & 0,218 & 0,743 \\
Lcontrol & Pretis & 0,335 & - & 0,335 \\
\hline
\end{tabular}

Sumber : data primer diolah 2014 
Hipotesis 3 menyatakan bahwa pemikiran moral berpengaruh tidak langsung terhadap prilaku etis profesi akuntan pendidik melalui locus of control. Berdasarkan tabel 5.16, besarnya pengaruh langsung pemikiran moral (Pmoral) terhadap prilaku etis profesi akuntan pendidik (Pretis) sebesar 0,130. Sedangkan pengaruh tidak langsung melalui locus of control (Lcontrol) sebesar 0,056 dengan pengaruh total sebesar 0,186. Hal ini membuktikan bahwa pengaruh pemikiran moral terhadap prilaku etis profesi akuntan pendidik cenderung bersifat langsung atau tidak melalui locus of control. Selain itu, karena pengaruh antara ketiga variabel tersebut adalah tidak signifikan maka artinya bahwa locus of control tidak dapat menjadi mediasi antara pemikiran moral dengan prilaku etis profesi akuntan pendidik. Dengan demikian hipotesis 3 ditolak.

Hipotesis 4 menyatakan bahwa pengalaman profesi berpengaruh tidak langsung terhadap prilaku etis profesi akuntan pendidik melalui locus of control. Berdasarkan tabel 5.16 , besarnya pengaruh langsung pengalaman profesi (Pprof) terhadap perilaku etis profesi akuntan pendidik (Pretis) sebesar 0,525. Sedangkan pengaruh tidak langsung melalui locus of control (Lcontrol) sebesar 0,218 dengan pengaruh total sebesar 0,743. Hal ini membuktikan bahwa pengaruh pengalaman profesi terhadap prilaku etis profesi akuntan pendidik cenderung bersifat langsung atau tidak melalui locus of control. Namun demikian, karena pengaruh ketiga variabel tersebut adalah signifikan maka dapat berarti bahwa locus of control menjadi mediasi antara pengalaman profesi dengan prilaku etis profesi akuntan pendidik. Dengan demikian hipotesis 4 dapat diterima.

Berdasarkan pengujian hipotesis di atas, secara ringkas diperoleh hasil sebagai berikut:

\begin{tabular}{|c|c|c|}
\hline No & Hipotesis & Kesimpulan \\
\hline 1. & $\mathrm{H} 1=\begin{array}{c}\text { Pemikiran moral berpengaruh secara langsung } \\
\text { terhadap prilaku etis profesi akuntan pendidik. }\end{array}$ & Ditolak \\
\hline 2. & $\mathrm{H} 2=\begin{array}{c}\text { Pengalaman profesi berpengaruh secara langsung } \\
\text { terhadap prilaku etis profesi akuntan pendidik. }\end{array}$ & Diterima \\
\hline 3. & $\mathrm{H} 3=\begin{array}{c}\text { Pemikiran moral berpengaruh tidak langsung } \\
\text { terhadap prilaku etis profesi akuntan pendidik } \\
\text { melalui locus of control. }\end{array}$ & Ditolak \\
\hline 4. & $\mathrm{H} 4=\begin{array}{c}\text { Pengalaman profesi berpengaruh tidak langsung } \\
\text { terhadap prilaku etis profesi akuntan pendidik } \\
\text { melalui locus of control. }\end{array}$ & Diterima \\
\hline
\end{tabular}

\section{Pembahasan}

\section{Pengaruh Pemikiran Moral terhadap Perilaku Etis Akuntan Pendidik}

Hasil pengujian terhadap $\mathrm{H}_{1}$ menemukan bahwa pemikiran moral tidak berpengaruh secara signifikan terhadap perilaku etis akuntan pendidiki. Pengaruh tersebut hanya sebesar 0,130 . Nilai critical ratio (CR) sebesar 1,022 dan nilai p-value pada tingkat signifikansi 0,307.

Temuan penelitian ini tidak konsisten dengan teori yang ada serta tidak mendukung beberapa hasil penelitian sebelumnya yang menyatakan bahwa pemikiran moral akan mudah membuat pertimbangan moral dan perilaku moral. Pemikiran moral akan mudah membuat pertimbangan moral dan perilaku moral. Kemudahan ini akan mencerminkan hak yang lebih tinggi dari pengembangan kognitif dalam pertimbangan dan perilaku. Pemikiran moral mengacu pada penggunaan beberapa alasan untuk menilai sesuatu kegiatan bisnis sebagai etika atau bukan. 
Apabila dilihat dari hasil pengujian penelitian ini, menunjukkan bahwa pengaruh pemikiran moral terhadap prilaku etis profesi akuntan pendidik cenderung bersifat langsung. Selain itu, karena pengaruh antara ketiga variabel tersebut adalah tidak signifikan sehingga hal ini membuktikan secara empiris bahwa locus of control tidak dapat menjadi mediasi antara pemikiran moral dengan prilaku etis profesi akuntan pendidik khususnya di Propinsi Lampung.

Secara teori, terdapat empat gaya pemikiran moral yang mencerminkan hirarki dari pengembangan moral, yang mengingatkan apa tujuan pengembangan moral (Kohlberg et al., 1983). Pertama, pemikiran deontological berfokus pada maksud untuk merealisasikan tujuan-tujuan yang penting, ideal, dan nilai-nilai yang diinginkan secara umum, yaitu meliputi kesetiaan. Kedua, pemikiran teleological menekankan dalam maksimalisasi yang bermanfaat untuk masyarakat atau sebanyak-banyaknya orang. Pada pendekatan teleological, perhatian tidak hanya pada perilaku dan tindakan, namun lebih pada bagaimana mencapai tujuan dengan sebaik-baiknya. Ketiga, utilitarianisme menyatakan bahwa perbuatan disebut etis jika membawa manfaat bagi masyarakat secara keseluruhan. Sedangkan keempat, egoisme berarti bahwa satu-satunya tujuan tindakan moral setiap orang adalah mengejar kepentingan pribadi dan memajukan dirinya.

\section{Pengaruh Pengalaman Profesi terhadap Perilaku Etis Akuntan Pendidik}

Hasil pengujian terhadap $\mathrm{H}_{1}$ menemukan bahwa pengalaman profesi berpengaruh secara signifikan terhadap perilaku etis akuntan pendidik. Pengaruh tersebut sebesar 0,525 . Nilai critical ratio (CR) sebesar 3,342 dan nilai p-value pada tingkat signifikansi 0,000 .

Temuan penelitian ini konsisten dengan teori yang ada dan mendukung beberapa hasil penelitian sebelumnya yang menyatakan bahwa pengalaman profesi akan mempermudah seseorang membuat pertimbangan moral dan perilaku moral. Beberapa pengalaman profesi yang relevan dapat mempengaruhi sikap etis apabila pengalaman profesi tersebut meninggalkan kesan yang kuat. Kesan positif yang kuat dapat terbentuk apabila pengalaman profesi tersebut terjadi dalam situasi yang melibatkan faktor emosional. Sikap etis secara otomatis akan memunculkan perilaku etis juga. Barney (1992 dalam Beekun 1997: 7), berpendapat bahwa pengalaman profesi seseorang baik yang positif maupun negatif merupakan kunci yang menjadi dasar munculnya sikap dan perilaku selanjutnya. Apabila seseorang dapat mengambil pelajaran dari pengalaman profesinya masa lalu maka akan menumbuhkan sikap dan perilaku yang semakin etis.

Apabila dilihat dari hasil pengujian penelitian ini, menunjukkan bahwa besarnya pengaruh langsung pengalaman profesi terhadap perilaku etis profesi akuntan pendidik sebesar

0,525 .

Sedangkan pengaruh tidak langsung melalui locus of control sebesar 0,218 dengan pengaruh total sebesar 0,743 . Hal ini membuktikan bahwa pengaruh pengalaman profesi terhadap prilaku etis profesi akuntan pendidik cenderung bersifat langsung atau tidak melalui locus of control. Namun demikian, karena pengaruh ketiga variabel tersebut adalah signifikan maka dapat berarti bahwa locus of control menjadi mediasi antara pengalaman profesi dengan prilaku etis profesi akuntan pendidik khususnya di Propinsi Lampung. 


\section{Pengaruh Mediasi Locus of Control terhadap Perilaku Etis Akuntan Pendidik}

Locus of control akan memperlihatkan bagaimana seseorang itu pandai mengendalikan perasaan dan emosi pada setiap kondisi yang melingkupinya. Bagaimanapun juga seseorang yang cerdas bukanlah hanya cerdas dalam hal intelektualnya saja tetapi intelektualitas tanpa adanya Locus of control dapat melahirkan perilaku yang tidak etis. Oleh karenanya, Locus of control dapat memediasi baik pemikiran moral maupun pengalaman profesi bagi pembentukan perilaku etis seseorang.

Brownell (1982) menyatakan bahwa Locus of control merupakan salah satu faktor individual yang mempengaruhi cara pandang seseorang terhadap suatu peristiwa, bisa tidaknya ia mengendalikan peristiwa tersebut, serta dorongan untuk menjadi seseorang sesuai dengan ambisinya (Robbins, 2006). Locus of control mengenai kekuatan-kekuatan dari gaya yang dipercaya oleh seorang individu sebagai bentuk tanggung jawab terhadap ganjaran dan hukuman yang terjadi padanya (Rotter, 1966). Seseorang yang dicirikan sebagai "eksternal" percaya bahwa dia adalah seorang korban dari nasib, kesempatan, kekuasaan yang lain dan bahwa dia sedikit memiliki control mengenai nasib baik atau keuntungan yang akan menimpanya.

Sebaliknya, seseorang yang "internal" percaya bahwa tingkah laku seseorang menentukan apa yang akan terjadi pada seseroang adalah pemilik nasib baik seseorang. Locus of control telah dianggap suatu dari ciri watak kepribadian yang lebih teguh atau stabil yang ada pada diri seorang individu (Koford dan Pennu, 1992). Dalam literatur moral menyatakan bahwa locus of control sebagai suatu ciri watak kepribadian memberikan pengaruh pada pembuatan keputusan dan tingkah laku (Chiu, 2003 dalam Chan dan Leung, 2006).

Berdasarkan hasil pengujian penelitian menunjukkan bahwa bahwa locus of control tidak dapat menjadi mediasi antara pemikiran moral dengan prilaku etis profesi akuntan pendidik. Namun demikian, untuk pengaruh pengalaman profesi terhadap prilaku etis profesi akuntan pendidik tersebut adalah signifikan maka dapat berarti bahwa locus of control menjadi mediasi antara pengalaman profesi dengan prilaku etis profesi akuntan pendidik khususnya di Propinsi Lampung.

\section{PENUTUP}

Berdasarkan penelitian yang dilakukan mengenai faktor-faktor yang mempengaruhi perilaku etis profesi akuntan pendidik di Propinsi Lampung, dapat disimpulkan sebagai berikut:

a) Pemikiran moral tidak berpengaruh secara signifikan terhadap perilaku etis akuntan pendidiki.

Temuan penelitian ini tidak konsisten dengan teori yang ada serta tidak mendukung beberapa hasil penelitian sebelumnya yang menyatakan bahwa pemikiran moral akan mudah membuat pertimbangan moral dan perilaku moral.

b) Pengaruh pemikiran moral terhadap prilaku etis profesi akuntan pendidik cenderung bersifat langsung. Selain itu, karena pengaruh antara ketiga variabel tersebut adalah tidak signifikan sehingga hal ini membuktikan secara empiris bahwa locus of control tidak dapat menjadi mediasi antara pemikiran moral dengan prilaku etis profesi akuntan pendidik khususnya di Propinsi Lampung.

c) Pengalaman profesi berpengaruh secara signifikan terhadap perilaku etis akuntan pendidik. Temuan penelitian ini konsisten dengan teori yang ada dan mendukung beberapa hasil penelitian sebelumnya yang menyatakan bahwa pengalaman profesi 
akan mempermudah seseorang membuat pertimbangan moral dan perilaku moral. Beberapa pengalaman profesi yang relevan dapat mempengaruhi sikap etis apabila pengalaman profesi tersebut meninggalkan kesan yang kuat. Kesan positif yang kuat dapat terbentuk apabila pengalaman profesi tersebut terjadi dalam situasi yang melibatkan faktor emosional. Sikap etis secara otomatis akan memunculkan perilaku etis juga.

d) Pengaruh pengalaman profesi terhadap prilaku etis profesi akuntan pendidik cenderung bersifat langsung atau tidak melalui locus of control. Namun demikian, karena pengaruhnya terjadi secara signifikan maka dapat disimpulkan bahwa locus of control menjadi mediasi antara pengalaman profesi dengan prilaku etis profesi akuntan pendidik khususnya di Propinsi Lampung.

Berdasarkan hasil penelitian ini, diharapkan bagi pengambil keputusan, sebaiknya memperhatikan berbagai faktor yang perlu dipertimbangkan dalam peningkatan perilaku etis profesi akuntan pendidik, yaitu meliputi: pengalaman profesi dan locus of control. Karena faktor inilah yang secara langsung maupun tidak langsung berpengaruh terhadap perilaku etis tersebut. Sedangkan faktor pemikiran moral meskipun berpengaruh namun kurang signifikan terhadap pembentukan perilaku etis akuntan pendidik. Bagi akademisi, hasil penelitian ini dapat dijadikan sebagai salah satu sumber referensi penelitian ataupun penyusunan karya ilmiah. Namun, karena penelitian dengan pengujian Structural Equation Modelling (SEM) mensyaratkan tingkat/ukuran sampel yang relatif besar sehingga sulit dipenuhi dalam penelitian ini. Oleh karena itu untuk penelitian-penelitian berikutnya diharapkan dapat menambah ukuran sampel sesuai yang disyaratkan dalam alat uji tersebut.

\section{DAFTAR PUSTAKA}

Allen, N.J., \& Meyer, J.P.1990. The measurement and antecedents of affective, continuance and normative commitment to the organization. Journal of Occupational, British 63, 1-18

Arens, A. A and Loebbecke, James. K. 1997. "Auditing an Integrated Approach". 8th Ed. Engelwood Cliff. Prentice Hall

Beekun, Rafik I, 1997, Islamic Business Ethics, International Institute of Islamic Thought, Virginia, USA

Chan, Samuel Y.S. and Leung, Philomena. 2006. "The effect of accounting student's ethical reasoning and personel factors on their ethical sensitivity", Managerial Auditing Journal, Vol. 21, No. 4, pp. 436-457.

Cropanzano, R., Prehar, C.A., \& Chen, P.Y. 2000. Using social exchange theory to distinguish procedural from interactional justice. Group \& Organization Mangement 27, 324-351

Falah. S. 2007. "Pengaruh Budaya Etis Organisasi dan Orientasi Etika Terhadap Sensitivitas Etika”. Simposium Nasional Akuntansi X Makasar, 26-28 Juli 
Ferdinand, A. 2006. Structural equation modeling dalam penelitian manajemen. Edisi 5. Badan Penerbit Universitas Diponegoro, Semarang

Fraedrich, J.P., \& Ferrell, O.C. 1992a. Cognitive consistency of marketing managers in ethical situations, Journal of Academy of Marketing Science, 20, 245-252.

Griffin, Rizky W., dan R. J Ebert. 1998. Business. Fourth Edition. Prentice Hall Inc. Englewood. Clift

Haris, J.R., and C. D. Sutton. 1995. “Unravelling the Ethical Decision-Making Process: Clues from an empirical study comparing fortune 1000 executives and MBA students", Journal of Business Ethics, 14, 805-817.

Imam, Gozali. 2008. Model Persamaan Struktural : Konsep dan aplikasi dengan program AMOS Ver. 5.0. Badan Penerbit Universitas Diponegoro, Semarang

Keraf, Sonny 1998. Etika Bisnis Tuntutan dan Relevansinya, Kanisius, Yogyakarta

Khomsiyah dan N. Indriantoro. 1998. "Pengaruh Orientasi Etika terhadap Komitmen dan Sensitivitas Etika Auditor Pemerintah di DKI Jakarta”. Jurnal Riset Akuntansi Indonesia. vol.1 Januari hal. 13 - 28

Kohlberg, L. 1983. The cognitive-developmental approach to moral education. Dlm. Rogrs, D. Issues in adolescent psychology: 283-299. New Jersey: Printice Hall, Inc.

Larkin, Joseph M. 2000. "The Ability of Internal Auditors to Identify Ethical Dilemmas". Journal of Business Ethics 23: 401-409

Maryani dan Ludigdo. 2001. "Faktor-faktor yang Mempengaruhi Sikap dan Perilaku Etis Akuntan”. TEMA, Volume II, Nomor 1, Maret

Morgan, Ronald B. 1993. "Self and Co-Worker Perceptions of Ethics and Their Relationship to Leadership and Salary". Academy of Management Journal 36: 200-214

Nugrahaningsih. 2005. “Analisis Perbedaan Perilaku Etis Auditor di KAP dalam Etika Profesi (Studi Terhadap Peran Faktor-faktor Individual: Locus of Control, Lama Pengalaman Kerja, Gender, dan Equity Sensitivity)". SNA VIII Solo, 15-16 September

Reiss, Michelle C., and Kaushik Mitra. 1998. "The effect of Individual Difference Factors on the Acceptibility of Ethical and Unethical Workplace Behaviors" Journal of Business Ethics. Vol. 17: 1581-1593.

Robbins, S.P. 2006. Perilaku Organisasi. Jilid 1 edisi Indonesia. PT. Indeks Kelompok Gramedia, Jakarta. 
Rotter, J.B. 1966. "Generalized expectancies for internal versus external control of reinforcement", Psychological Monograph, General and Applied, Vol. 80 No. 1, (Whole No. 609).

Smith, H., \& Tyler, T. 1997. Choosing the right pond: the impact of group membership on self-esteem and group-oriented behavior. Journal of Experimental Social Psychology 33, 146-170 